\title{
TINGKAT KECEMASAN DAN STRES PADA MAHASISWA YANG MENGIKUTI OBJECTIVE STRUCTURE CLINICAL EXAMINATION (OSCE)
}

\author{
Vina Rachmawati ${ }^{* *}$, Mustikasari ${ }^{2}$ \\ ${ }^{1}$ Program Studi Sarjana Fakultas Ilmu Keperawatan Universitas Indonesia, Depok, \\ J1. Prof. Dr Bahder Djohan, Jawa Barat, 16424 Indonesia \\ ${ }^{2}$ Departemen Jiwa Fakultas Ilmu Keperawatan Universitas Indonesia, Depok, \\ J1. Prof. Dr Bahder Djohan, Jawa Barat, 16424 Indonesia \\ Email: Vinarachmawati50@gmail.com
}

\begin{abstract}
ABSTRAK
Penelitian ini membahas mengenai tingkat kecemasan dan stres yang dialami oleh mahasiswa mengikuti OSCE. Tujuan: Penelitian ini bertujuan untuk menggambarkan tingkat kecemasan dan stres pada mahasiswa yang mengikuti OSCE. Metode: Penelitian ini melibatkan 109 responden dengan kriteria inklusi yaitu mahasiswa aktif dan sudah mengikuti ujian OSCE praktikum anak. Penelitian ini menggunakan total sampling. Instrumen yang digunakan yaitu Hamilton Rating Scale Anxiety (HRS-A) dan Perceived Stress Scale (PSS). Uji reliabilitas instrumen HRS-A memiliki nilai Cronbanch's Alpa yaitu 0,752 dan uji reliabilitas instrumen PSS memiliki nilai Cronbanch's Alpa yaitu 0,706. Data dianalisis secara univariat. Hasil penelitian: mahasiswa yang mengalami kecemasan ringan yaitu 71 (65,14\%), kecemasan sedang 19 $(17,43 \%)$, kecemasan berat $17(15,6 \%)$, dan panik 2 (1,83\%. Mahasiswa yang mengalami stres ringan $1(0,9 \%)$, stres sedang 78 (71,6\%) dan stres berat 30 (27,5\%). Kesimpulan: Hasil penelitian ini diharapkan bisa memberikan informasi bagi institusi pendidikan mengenai gambaran tingkat kecemasan dan stres pada mahasiswa yang mengikuti OSCE. Sebagian mahasiswa mengalami kecemasan sedang berat dan panik sehingga perlu penelitian lanjutan tentang faktor faktor yang mempengaruhi tingkat stres dan kecemasan serta strategi koping yang digunakan dalam mengatasi kondisi stres yang muncul saat melaksanakan OSCE.
\end{abstract}

Kata Kunci: Kecemasan, stres, mahasiswa keperawatan dan OSCE

\section{Anxiety and Stress Level in Students Who Take Objective Structure Clinical Examination (OSCE)}

\section{ABSTRACT}

This study discusses the level of anxiety and stress experienced by students following the OSCE. Objective: This study aims to describe the level of anxiety and stress in students who take OSCE. Method: This study involved 109 respondents with inclusion criteria, namely active students who had taken the OSCE examination for their practicum. This research uses total sampling. This research has successfully passed the ethical test. The instruments used were Hamilton Rating Anxiety Scale (HRS-A) and Perceived Stress Scale (PSS). The reliability test of the HRS-A instrument has a Cronbanch's Alpa value of 0.752 and the reliability test of the PSS instrument has a Cronbanch's Alpa value of 0.706. Data was analysed with univariate analysis. Results: The results showed that of 109 respondents, students experienced mild anxiety, namely 71 (65.14\%), moderate anxiety 19 (17.43\%) and severe anxiety 17 (15.6\%) and panic 2 (1.83\%). The results showed that of 109 respondents, students who experienced mild stress 1 (0.9\%), moderate stress 78 (71.6\%) and severe stress 30 (27.5\%) Conclusion: The results of this study are expected to provide information for educational institutions regarding the description of anxiety and stress levels in students who take part in OSCE Some students experience moderate anxiety and panic, so it is necessary to further research on the factors that influence stress and anxiety levels and coping strategies used in dealing with stress conditions that arise when implementing OSCE.

Keywords: anxiety, stress, nursing student and OSCE 


\section{LATAR BELAKANG}

Pendidikan keperawatan adalah pendidikan bersifat akademik yang bermakna yaitu program pendidikan memiliki landasan akademik dan profesi yang cukup (Nursalam \& Efendi, 2008). Pengujian klinik atau lapangan merupakan salah satu hal yang dapat dijadikan untuk menentukan kompetensi mahasiswa. Objective Structure Clinical Examination (OSCE) dapat digunakan untuk meningkatkan pendidikan keperawatan (Brighton dkk, 2017). OSCE adalah metode evaluasi yang digunakan untuk menilai kemampuan klinik seorang mahasiswa secara terstruktur dan objektif (Nursalam \& Efendi, 2008). Ada beberapa metode evaluasi klinik yaitu tertulis, observasi, wawancara, dan penerapan OSCE (Zabar dkk., 2013). Pada penelitian yang dilakukan Brighton dkk (2017) pada mahasiswa keperawatan dilaporkan bahwa ujian OSCE penuh tekanan dan dapat membuat stres.

Ansietas adalah perasaan ketidaknyaman dari kekhawatiran atau ketakutan yang terjadi akibat respon terhadap stimulus internal dan eksternal dan dapat menghasilkan tanda fisik, emosional, kognitif, dan sikap (Boyd, 2017). Ansietas dapat terjadi ketika seseorang merasa khawatir tentang kondisi yang terjadi. Ansietas dapat menjadi hal yang positif jika seseorang melawan kecemasannya dan berbuat yang terbaik. Jika mahasiswa tidak dapat mengatasi ancaman tersebut maka seseorang akan cenderung untuk merasa cemas (Keltner, Bostrom, \& McGuinnes, 2011). Kecemasan itu dapat terjadi salah satunya karena seorang mahasiswa ingin mendapatkan nilai yang terbaik pada saat ujian.

Penelitian yang dilakukan oleh Longyhore (2017) menjelaskan bahwa rentang mahasiswa farmasi untuk kecemasan terhadap OSCE adalah 35,7 sampai 36,5 untuk pria dan 35,2 sampai 38,8 untuk wanita. Hasil penelitian sebelumnya tentang hubungan tidur dengan tingkat stres, kecemasan dan depresi pada mahasiswa FIK UI mengungkapkan bahwa kecemasan pada mahasiswa terdiri dari ringan sampai berat. Persentase untuk cemas ringan yaitu $29,5 \%$, cemas sedang yaitu $11,8 \%$, cemas berat yaitu $12,3 \%$ dan cemas sangat berat yaitu 12,3\% (Dwi M, 2014).

Stres merupakan suatu bentuk dari stresor itu sendiri. Stres juga dapat diartikan sebagai respon individu ketika terjadi perubahan dalam status keseimbangan normal (Berman, Snyder, \& Frandsen, 2016). Stres dapat disebabkan oleh tujuan hidup individu, kepercayaan individu terhadap diri sendiri dan dunia, dan sumber daya personal. Pengaruh stres dapat berdampak pada fisik, emosi, intelektual, sosial dan spiritual (Berman, Snyder, \& Frandsen, 2016). Akibat yang terjadi jika mahasiswa mengalami stres dapat berdampak pada emosinya seperti timbulnya perasaan negatif dan rendah diri terhadap ujian OSCE. Fenomena, konsep, teori dan dari hasil penelitian di atas membuat peneliti tertarik untuk mengetahui gambaran tingkat kecemasan dan stres pada mahasiswa yang mengikuti OSCE.

\section{METODE}

Penelitian ini menggunakan desain deskriptif. Tempat penelitian ini berada di Fakultas IImu Keperawatan Universitas Indonesia. Sampel penelitian diambil dengan cara total sampling pada 110 mahasiswa yang terdiri dari satu angkatan 2015 program S1 Reguler. Mahasiswa FIK UI 2015 Program Reguler yang masuk ke dalam kriteria inklusi sebanyak 109 orang. Pada penelitian ini, kriteria inklusi yaitu mahasiswa program S1 reguler FIK UI 2015 yang mengikuti ujian OSCE praktikum keperawatan anak. 
Proses pengumpulan data menggunakan dua kuesioner yaitu Perceived Stress Scale (PSS) dan kuesioner Hamilton Rating Scale Anxiety (HRS-A). Kuesioner Hamilton Rating Scale Anxiety (HRS-A) digunakan untuk mengukur tingkat kecemasan pada saat ujian OSCE. Sedangkan Perceived Stress Scale (PSS) digunakan untuk mengukur tingkat stres pada saat ujian OSCE.

Penelitian yang dilakukan terhadap mahasiswa FIK UI 2016 menyatakan bahwa uji reliabilitas instrumen HRS-A baik dan memiliki nilai Cronbanch's Alpa yaitu 0,752 dan uji reliabilitas instrumen $P S S$ baik dan memiliki nilai Cronbanch's Alpa yaitu 0,706. Uji validitas pada instrument HRS-A memiliki nilai di atas 0,05 untuk setiap nomor. Pada instrument PSS, uji validitas memiliki nilai di atas 0,05 kecuali nomor 4 dan 8 . Uji validitas pada kuesioner Hamilton Rating Scale Anxiety menyatakan bahwa semua nomor valid dan untuk kuesioner PSS menyatakan bahwa ada 2 nomor yang lemah. Nomor tersebut ialah 4 dan 8 . Untuk mengatasi hal tersebut maka peneliti memutuskan untuk mengganti kedua kalimat tersebut menjadi kalimat yang mudah dipahami. Peneliti mengganti kalimat no. 4 menjadi "pernahkah Anda merasa yakin dengan kemampuan Anda untuk menangani kinerja Anda selama OSCE?". Peneliti mengganti kalimat no. 8 menjadi "pernahkah Anda merasa bahwa Anda berada di atas segalanya karena berhasil menyelesaikan segalanya selama OSCE?". Hasil dari penelitian kuantitatif ini akan diuraikan dengan analisis univariat yang menampilkan karakteristik responden dan pengukuran variabel dan sub variabel. Penelitian ini telah lolos uji etik. Persetujuan etik yang diterapkan pada penelitian ini mengutamakan prinsip manfaat, menghargai hak asasi manusia dengan memberikan kebebasan untuk ikut atau dan menjaga kerahasiaan responden.

\section{HASIL}

Hasil penelitian ini menunjukkan data responden berdasarkan usia yaitu berkisar 20-23 tahun dan CI 95\% sekitar 20,43 sampai 20,66 . Usia termuda 20 tahun dan tertua adalah 23 tahun. Peneliti menggunakan nilai tengah karena penyebaran distribusi yang tidak normal pada karakteristik usia. Nilai median (tengah) untuk usia pada mahasiswa FIK UI 2015 yaitu 20.

\section{Tabel 1. Distribusi Frekuensi Mahasiswa $(n=109)$}

\begin{tabular}{llcc}
\hline Variabel & Kategori & Frekuensi & $\begin{array}{c}\text { Persentase } \\
\text { (\%) }\end{array}$ \\
\hline Jenis & Laki-laki & 4 & 3,7 \\
Kelamin & Perempuan & 105 & $96,3 \%$ \\
\hline Kece- & Kecemasan & 71 & 65,14 \\
masan & ringan & & \\
& Kecemasan & 19 & 17,43 \\
& sedang & & \\
& kecemasan & 17 & 15,6 \\
& berat & & \\
& Panic & 2 & 1,83 \\
\hline Stres & stres ringan & 1 & 0,9 \\
& stres sedang & 78 & 71,6 \\
& stres berat & 30 & 27,5 \\
\hline
\end{tabular}

Berdasarkan tabel 1, mayoritas responden berjenis kelamin perempuan, yaitu sebanyak 105 orang (96,3\%). Mayoritas mahasiswa mengalami kecemasan ringan yaitu 71 (65,14\%). Mahasiswa FIK UI saat menghadapi ujian OSCE mengalami stres ringan sampai dengan stres berat. Mayoritas mahasiswa FIK UI mengalami stres sedang sebanyak $78(71,6 \%)$.

\section{DISKUSI}

Hasil penelitian ini menyebutkan bahwa mayoritas mahasiswa yang mengikuti ujian OSCE berkisar usia 20 tahun. Pada usia ini, mahasiswa memasuki tahap dewasa awal. Penelitian tersebut sejalan dengan penelitian yang dilakukan oleh Heinke, 
dkk (2013) pada mahasiswa di London yang mengatakan bahwa rata-rata usia mahasiswa yang menjalani ujian OSCE yaitu 24 tahun. Selain itu sejalan dengan penelitian yang dilakukan pada mahasiswa keperawatan di New York oleh McWilliam, dkk (2012) yang mengatakan bahwa rentang usia mahasiswa yang mengikuti OSCE yaitu 21 sampai 23 tahun. Pada penelitian selanjutnya yang dilakukan oleh Kalantari, dkk (2017) pada mahasiswa kedokteran di Mumbai mengatakan bahwa populasi penelitian terdiri atas 138 mahasiswa yang memiliki rata-rata usia yaitu 22 tahun.

Mahasiswa FIK UI 2015 lebih banyak yang berjenis kelamin perempuan dibandingkan dengan laki-laki. Pada penelitian ini mayoritas responden berjenis kelamin perempuan. Hal ini sejalan dengan penelitian penelitian yang dilakukan sebelumnya mengenai ujian OSCE. Penelitian ini sejalan dengan yang dilakukan oleh Heinke, dkk (2013) pada mahasiswa di London yang mengatakan bahwa mayoritas mahasiswa yang mengikuti ujian OSCE yaitu perempuan.

Ansietas atau kecemasan adalah ketakutan yang menyebar dan tidak jelas yang terkait dengan ketidakpastian dan ketidakberdayaan (Townsend, 2014). Ansietas adalah perasaan ketidaknyaman dari kekhawatiran atau ketakutan yang terjadi akibat respon terhadap stimulus internal dan eksternal dan dapat menghasilkan tanda fisik, emosional, kognitif, dan sikap (Boyd, 2017). Ansietas merupakan respon dari stres yang dihadapi setiap hari di kehidupannya (Keltner, Bostrom, \& McGuinnes, 2011). Ada banyak faktor yang dapat mempengaruhi kecemasan pada seseorang seperti usia dan jenis kelamin.

Pada penelitian sebelumnya yang dilakukan oleh Stuart \& Sundeen (2008), usia mempengaruhi seseorang. Semakin tinggi usianya maka akan semakin baik tingkat kemampuannya dalam menghadapi berbagai macam persoalan sehingga dapat mengurangi tingkat kecemasan yang dimiliki oleh seseorang. Selain itu pendidikan sebelumnya juga dapat memengaruhi tingkat kecemasan yang dialami oleh seseorang.

Hasil penelitian ini menunjukkan bahwa mahasiswa ada yang mengalami tingkat kecemasan yang sedang bahkan sampai tingkat panik. Hal ini dapat menimbulkan beberapa masalah seperti masalah kosentrasi dan berfikir selama ujian OSCE berlangsung. Pada tingkat kecemasan sedang, individu mulai tidak memperdulikan sekitar (Townsend, 2014). Pada tingkat berat, individu akan mulai kehilangan kosentrasi terhadap perubahan yang terjadi. Hal ini sejalan dengan penelitian yang dilakukan oleh Kalantari, dkk (2017) pada mahasiswa kedokteran di Mumbai mengatakan bahwa semakin tinggi kecemasan individu maka tidak akan diragukan lagi dapat mengganggu fungsi intelektual sementara dan individu yang panik tidak dapat menggunakan seluruh fungsi tubuhnya dengan baik. Rentang perhatian akan sangat terbatas dan individu akan mengalami kesulitan untuk menyelesaikan tugas bahkan untuk tugas yang sederhana. Pada tahap panik individu tidak akan bisa fokus pada satu hal, persepsi yang salah terjadi, kehilangan kontak dan terkadang individu mengalami halusinasi atau delusi (Townsend, 2014). Hal ini selaras dengan penelitian yang dilakukan oleh Praptiningsih (2016) yang mengatakan bahwa kecemasan yang dialami selama ujian OSCE dapat mengganggu kemampuan memusatkan perhatian menurunkan daya ingat serta mempengaruhi performa selama OSCE berlangsung.

Pada penelitian yang dilakukan pada mahasiswa regular FIK UI 2015 yang baru pertama kali menghadapi ujian OSCE, mayoritas responden menyatakan bahwa mengalami kecemasan ringan sebanyak 
71 orang $(65,14 \%)$. Penelitian ini dilakukan dengan menggunakan kuisioner Hamilton Rating Scale Anxiety dan didapatkan data bahwa mahasiswa FIK UI 2015 mengalami tingkat kecemasan dari ringan sampai panik. Mahasiswa yang mengalami panik sekitar $2(1,83 \%)$, kecemasan sedang sekitar 19 $(17,43 \%)$ dan kecemasan berat sekitar 17 $(15,6 \%)$.

Hasil penelitian ini sesuai dengan hasil penelitian sebelumnya mengenai tingkat kecemasan dalam menghadapi OSCE pada anak Fakultas Kedokteran oleh Yuhelrida, dkk (2016) yang didapatkan dari 28 responden. Penelitian tersebut menunjukkan bahwa yang mengalami kecemasan berat sebanyak 10 orang $(35,7 \%)$, kecemasan sedang sebanyak 6 orang $(21,6 \%)$, kecemasan ringan sebanyak 6 orang $(21,6 \%)$, dan tidak cemas sebanyak 5 orang $(17,9 \%)$. Pada penelitian tersebut didapatkan bahwa mayoritas mahasiswa mengalami kecemasan berat.

Mahasiswa FIK UI 2015 program regular yang mengalami kecemasan berat sebanyak 17 orang dan panik sebanyak 2 orang. Hal ini perlu diatasi segera. Individu yang mengalami kecemasan dapat melakukan beberapa hal yang dapat membantu untuk mengurangi kecemasan sebelum menghadapi ujian OSCE, misalnya dengan teknik relaksasi. Berman, Snyder, \& Frandsen (2016) dalam bukunya menjelaskan bahwa teknik relaksasi dapat berupa teknik nafas dalam, terapi musik, pijat, dan sentuhan terapeutik. Hal ini juga sesuai dengan penelitian yang dilakukan oleh Sellakumar (2015) selama 45 hari berturut turut yang menyatakan bahwa ada efek yang signifikan dari teknik nafas dalam terhadap siswa yang mengalami cemas. Hal tersebut dapat dilakukan pada mahasiswa untuk mengurangi tingkat kecemasan mahasiswa dari sedang sampai dengan panik. Mahasiswa dapat melakukan tarik nafas dalam sebelum memasuki ruangan ujian OSCE.

Stres merupakan dorongan atau tekanan yang dapat terjadi dari dalam diri maupun faktor dari luar. Stres adalah suatu keadaan dimana individu berespon terhadap perubahan yang terjadi. Sedangkan stresor adalah pemicu atau stimulus yang bisa menyebabkan seseorang mengalami stres (Berman, Snyder, \& Frandsen, 2016). Hal ini dijelaskan oleh Potter \& Perry (2010) yang mengatakan bahwa pada saat dewasa muda seseorang akan memiliki stresor khusus, salah satunya Ujian OSCE memiliki serangkaian ujian dalam satu ruangan. Hal tersebut terkadang membuat mahasiswa mengalami stres. Pada penelitian ini menunjukkan bahwa Mahasiswa FIK UI saat menghadapi ujian OSCE mengalami stres ringan sampai dengan stres berat. Penelitian menunjukkan bahwa dari 109 mahasiswa yang mengalami stres sedang sebanyak 78 orang $(71,6 \%)$ dan stres berat sebanyak 30 orang $(27,5 \%)$. Mayoritas mahasiswa FIK UI mengalami stres sedang. Hasil penelitian di atas menunjukkan bahwa terdapat mahasiswa yang mengalami tingkat stres sedang sampai berat. Pada penelitiannya Hafezeqoran, dkk (2015) juga menyatakan bahwa mayoritas (90\%) mahasiswa mengalami tingkat stres yang tinggi selama ujian OSCE berlangsung. Selain itu penelitian yang dilakukan oleh Swift, dkk (2013) mengatakan bahwa 70\% dari 14 siswa mengalami stres saat ujian. Hasil penelitian tersebut menyatakan bahwa mahasiswa yang mengikuti ujian OSCE mengalami stres selama ujian berlangsung.

Penelitian yang dilakukan oleh McWilliam, dkk (2012) mengatakan bahwa menilai kompetensi klinis sebagai peluang untuk pengaturan perawatan pasien, OSCE ini dirancang dan diimplementasikan sebagai metode penilaian, menyediakan kompetensi klinik mahasiswa dengan mem- 
berikan kesempatan untuk menunjukkan ketrampilan interpersonal, pemecahan masalah, pengajaran dan aplikasi pengetahuan dasar klinis (McWilliam, dkk, 2012). Selain itu diperkuat dengan penelitian yang dilakukan oleh Swift, dkk (2013) yang mengatakan bahwa lokasi OSCE bisa menimbulkan tekanan tambahan pada individu. Hal ini sejalan dengan penelitian yang dilakukan oleh Kalantari, dkk (2017) pada mahasiswa kedokteran di Mumbai yang melaporkan bahwa prosedur pemeriksaan dan penilaian berpotensi menimbulkan kecemasan dan stres bagi mahasiswa. Hal ini sejalan dengan penelitian yang dilakukan oleh Delavar, dkk (2013) pada mahasiswa yang menyatakan bahwa sekitar separuh mahasiswa menyatakan bahwa OSCE merupakan penilaian yang penuh dengan tekanan dan sekitar $40 \%$ mahasiswa merasa bahwa OSCE penilaian yang menegangkan dan dapat membuat stres. Pada penelitian yang dilakukan Brighton, dkk (2017) pada mahasiswa keperawatan dilaporkan bahwa walaupun ujian OSCE penuh tekanan, OSCE dapat memberikan mahasiswa keyakinan pada kemampuan mereka. Hasil penelitian di atas membuktikan bahwa mahasiswa yang mengikuti ujian OSCE cenderung untuk mengalami masalah stres. Stres dapat berpengaruh terhadap kesehatan psikologis mahasiswa. Hal ini dijelaskan dan diperkuat dalam penelitian yang dilakukan oleh Fanning (2016) di Universitas Ohio yang mengatakan bahwa stres akademik menyumbang $11,7 \%$ kesehatan psikologis.

\section{SIMPULAN}

Karakteristik pada mahasiswa FIK UI 2015 program S1 Reguler di Rumpun IImu Kesehatan didapatkan bahwa mahasiswa memiliki nilai tengah umur yaitu 20 tahun. Jenis kelamin yang diambil dalam penelitian ini didominasi oleh perempuan. Sebagian besar mahasiswa mengalami tingkat kecemasan ringan.

Hasil penelitian ini diharapkan bisa memberikan informasi bagi pihak FIK UI mengenai gambaran tingkat kecemasan dan stres pada mahasiswa yang mengikuti OSCE. Penelitian ini juga dapat menjadi bahan evaluasi bagi sistem pembelajaran sehingga kedepannya bisa lebih baik dan kompetensi yang diharapkan dapat terpenuhi. Peneliti lain dapat mengembangkan penelitian dengan meneliti faktorfaktor yang mempengaruhi tingkat stres dan kecemasan serta strategi koping yang digunakan dalam mengatasi kondisi stres yang muncul saat melaksanakan OSCE.

\section{DAFTAR PUSTAKA}

Berman, A., Snyder, S.J., \& Frandsen, A.G. (2016). Fundamentals of nursing: concepts, process, \& practice. 10th ed. New Jersey: Pearson.

Boyd, M. A. (2017). Essentials of psychiatric nursing. Philadelphia: Lippincott, Williams \& Wilkins.

Brighton, R., Mackay, M., Brown, R. A., Jans, C., \& Antoniou, C. (2017). Introduction of undergraduate nursing students to an objective structured clinical examination. Journal of Nursing Education, 56(4): 231-234. http://dx.doi.org/10.3928/0148483420170323-08

Delavar, M. A., Salmalian, H., Faramarzi, M., Pasha, H., Bakhtiari, A., Nikpour, M., \& Ledari, F. M. (2013). Using the objective structured clinical examinations in undergraduate midwifery students. Journal of Medicine and Life, 6(1): 76-9. Retrieved from https://remote-lib. ui.ac.id:2063/docview/1345944593 ?accountid $=17242$

Dwi M, A. (2014). Hubungan Kualitas Tidur dengan Tingkat Stres, Kecemasan dan Depresi Pada Mahsiswa Ke- 
perawatan (Skripsi). Fakultas IImu Keperawatan Universitas Indonesia, Jakarta, Indonesia.

Fanning, G. G. (2016). Academic stress and academic self-efficacy as predictors of psychological health in college students (Doctoral dissertation, The Department of Counseling and Higher Education and The Patton College of Education, Ohio University, USA). Retrieved from https://remote-lib.ui.ac.id:2063/docv iew/1845865020?accountid=17242

Hafezeqoran, A., Moslehifard, E., \& Koodaryan, R. (2015). Attitude of dental prostheses residents of faculty of dentistry of tabriz university of medical sciences to objective structured clinical examination (OSCE). Research and Development in Medical Education, 4(2), 141-146. Retrieved from https://doi.org/10.15171/ rdme.2015.025

Heinke, W., Rotzoll, D., Hempel, G., Zupanic, M., Stumpp, P., Kaisers, U. X., \& Fischer, M. R. (2013). Students benefit from developing their own emergency medicine OSCE stations: A comparative study using the matched-pair method. BMC Medical Education, 13, 138.

Kalantari, M., Zadeh, N., Agahi, R., Navabi, N., Hashemipour, M., \& Nassab, A. (2017). Measurement of the levels anxiety, self-perception of preparation and expectations for success using an objective structured clinical examination, a written examination, and a preclinical preparation test in kerman dental students. Journal of Education and Health Promotion, 6(1): 28. Retrieved from doi:http://remote-lib.ui.ac. id:2073/10.4103/jehp.jehp_97_15

Keltner, N. L, Bostrom, C. E., McGuinnes, T.
(2011). Psychiatric Nursing. 6th edition. USA: Elsevier Mosby.

Longyhore, D. S. (2017). Pharmacy student anxiety and success with objective structured clinical examinations. American Journal of Pharmaceutical Education, 81(1): 1-6. Retrieved from https://search. proquest.com/docview/187605966 1 ? accountid $=17242$

McWilliam, P. L., \& Botwinski, C. A. (2012). Identifying strengths and weaknesses in the utilization of objective structured clinical examination (OSCE) in a nursing program. Nursing Education Perspectives, 33(1): 35-9.

Stuart, G. W. \& Sundeen. (2008). Buku saku keperawatan jiwa. Edisi 3. (Alih bahasa: Achir Yani). Jakarta: EGC.

Nursalam \& Efendi, F (2008). Pendidikan dalam Keperawatan. Jakarta: Salemba Medika.

Potter, Perry. (2010). Fundamental Of Nursing: Concept, Process and Practice. Edisi 7. Vol. 3. Jakarta: Penerbit Buku Kedokteran EGC.

Praptiningsih, R.S. (2016). Kecemasan Mahasiswa Menghadapi Objective Structured Clinical Examinations (OSCE). ODONTO Dental Journal, 3(2): 88-93.

Sellakumar, G. K. (2015). Effect of slowdeep breathing exercise to reduce anxiety among adolescent school students in a selected higher secondary school in coimbatore, india. Journal of Psychological and Educational Research, 23(1): 54-72. Retrieved from https://remote-lib. ui.ac.id:2063/docview/1689878021 ?accountid $=17242$

Swift, Marcie, P.T., Spake, Ellen, P.T. \& Gajewski, B. J. (2013). Student performance and satisfaction for a 
musculoskeletal objective structured clinical examination. Journal of Allied Health, 42(4): 214-22. Retrieved from https://remote-lib. ui.ac.id:2063/docview/1493992028 ?accountid $=17242$

Townsend, M. C. (2014). Psychiatric Mental Health Nursing: concepts of care in evidence-based practice. Philadelphia: F.A. Davis Company. Yuhelrida, Andriani, P., Sofya, A., \& Pocut. (2016). Tingkat Kecemasan Dalam
Menghadapi Objective Structured Clinical Examination (OSCE) (Studi pada peserta UKMP2DG Unsyiah Periode II Tahun 2016. Journal Caninus Dentristry, 1(4).

Zabar, S., Kalet, A., Krajic, K. E., Hanley, K. (eds.). (2013). Objective Structured Clinical Examinations, 10 Steps to Planning and Implementing OSCES and Other Standardized Patient Exercises. New York: Springer Science Business Media. 